\title{
UPAYA PENINGKATAN KEMAMPUAN GERAK MOTORIK MELALUI PERMAINAN LEMPAR TANGKAP BOLA
}

\author{
Rohmadi \\ SDN Karangtengah IV Wonosari \\ Email: rohmadi.rois@yahoo.com
}

\begin{abstract}
ABSTRAK
Pendidikan jasmani sebagai bagian integral dari pendidikan akan membantu para siswa untuk dapat menjalani proses pertumbuhan dan perkembangan secara optimal baik fisik, motorik, mental dan sosial. Tujuan pengembangan adalah aspek fisik akan berhubungan dengan kemampuan melakukan aktivitas-aktivitas yang melibatkan kekuatan fisik dan berbagai organ tubuh (physical fitness). Pengembangan gerak berhubungan dengan kemampuan melakukan gerak secara efektif, efisien, halus, indah, sempurna (skill full). Pengembangan mental berhubungan dengan kemampuan berfikir dan menginterprestasikan semua pengetahuan tentang pendidikan jasmani ke dalam lingkungan. Perkembangan sosial berhubungan dengan kemampuan siswa dalam menyesuaikan diri pada kelompoknya.Hakekat pendidikan jasmani adalah proses pendidikan via gerak insani (human movement) yang dapat berupa aktivitas jasmani, permainan dan olahraga. Pengembangan substansi pendidikan jasmani dan pendidikan olahraga pada dasarnya bertolak dari kaidah yang sama yaitu penyesuaian dengan kematangan atau kesiapan belajar anak. Salah satu upaya yang dapat dilakukan adalah melalui permainan lempar tangkap bola untuk mengembangkan motorik pada anak usia 8 s.d 9 tahun. Penelitian ini dilakukan untuk mengetahui seberapa berpengaruhnya permainan lempar tangkap bola terhadap kemampuan gerak anak.
\end{abstract}

Kata Kunci: , kemampuan, gerak motorik, permainan lempar tangkap bola

\section{PENDAHULUAN}

Kurikulum penjas, telah mengalami perubahan nama mata pelajaran dan substansinya, mulai dengan istilah Pendidikan Jasmani, Olahraga Kesehatan, Penjaskes, Penjas, dan terakhir Pendidikan Jasmani Olahraga dan Kesehatan. Pergantian nama kurikulum penjas ini, berkonsekuensi kepada perubahan berbagai infra struktur pembelajaran mulai dari penentuan tujuan, penentuan isi, proses (strategi dan pendekatan) serta evaluasinya.Namun demikian apapun istilahnya iklim belajar yang terjadi harus bersuasanakan ke SD-an. 
Kemampuan adalah suatu kapasitas individu untuk melaksanakan tugas dalam pekerjaan tertentu ,Stepen P. Robbins (2003:52). Kemampuan seseorang akan turut serta menentukan perilaku dan hasilnya. Yang dimaksud kemampuan adalah bakat yang melekat pada seseorang untuk melakukan suatu kegiatan secara phisik atau mental yang ia peroleh sejak lahir.

Tugas yang paling utama dalam menyelenggarakan pendidikan jasmani adalah bagaimana membantu para siswa untuk dapat menjalani proses pertumbuhan dan perkembangan secara optimal baik secara fisik, motorik, mental dan sosial. Belajar, seperti ditulis Rusli Lutan (2001: 7) adalah "perubahan perilaku sebagai hasil dari pengalaman, bukan karena pengaruh faktor keturunan atau kematangan."

Perubahan perilaku yang diharapkan dari belajar bersifat melekat secara permanen. Proses belajar itu sendiri tidak dapat diamati secara langsung. Namun demikian keterlaksanaannya hanya dapat ditafsirkan berdasarkan perilaku nyata yang diamati.

Perubahan-perubahan perilaku akan terjadi melalui proses mengajar yang disengaja, yang kebetulan, tidak disengaja, bahkan mungkin karena seseorang melakukan kesalahan-kesalahan belajar.

Pendidikan jasmani sebagai bagian integral dan merupakan alat pendidikan banyak didefinisikan dengan berbagai macam tekanan. Baik pada proses maupun tujuannya. Salah satunya dikutip Rusli Lutan sebagai berikut "pendidikan jasmani adalah bagian integral dari pendidikan melalui aktifitas jasmani yang bertujuan untuk meningkatkan individu secara organik, neuromuscular, intelektual, dan emosional." Pada hakekatnya ; "pendidikan jasmani adalah sebagai proses pendidikan via gerak insani (human movement) yang dapat berupa aktivitas jasmani, permainan atau olahraga untuk mencapai tujuan pendidikan" (Rusli Lutan : 7:1995-1996).

Selaras dengan upaya untuk mencapai tujuan pendidikan maka dalam pendidikan jasmani bukan saja dikembangkan dan dibangkitkan potensi individu tetapi juga ada unsur pendidikan yang dikembangkan meliputi aspek kemampuan 
fisik, intelektual, emosional, sosial dan moral spiritual yang berorientasi kepada life skill. Sasaran pendidikan jasmani adalah peningkatan kebugaran jasmani dan keterampilan gerak dasar yang kaya dengan koordinasi otot-otot saraf yang halus yang akan bermanfat bagi kelangsungan hidup sehari-hari dan menjadi pondasi yang kuat untuk suatu cabang olahraga. Kalaupun kita jumpai terdapat adeganadegan tugas yang memerlukan ketangkasan dan bahkan prestasi, namun demikian prestasi optimal, rekor, juara, tidak menjadi gol setting dalam pendidikan jasmani.

Pembinaan nalar anak melalui pemecahan masalah menjadi sangat penting untuk meningkatkan pencapaian domain kognitif dan afektif yang selama ini kurangdominan dalam pendidikan jasmani. Adegan pergaulan, kesetaraan kesempatan siswa laki-laki dan perempuan dan pengembangan sikap sosial merupakan sumbangan penting dalam pendidikan jasmani, kejujuran, sportifitas dan perbuatan fair yang menjadi nafas inti dalam olahraga merupaka invenstasi penting dalam pengembangan sosial.

Kalaupun olahraga bukan merupakan perpanjangan pendidikan jasmani, namun demikian kemampuan gerak dasar yang menyeluruh (general motor ability) akan menjadi landasan kuat bagi anak dalam penguasaan keterampilan olahraganya.

Pendidikan olahraga merupakan proses pendidikan yang mengarah pada pengenalan dan penguasaan keterampilan suatu cabang olahraga. Terdapat perbedaan pokok yang sangat jelas terutama dalam substansinya. Pendidikan jasmani akan mengarahkan proses belajar itu pada pengembangan keterampilan gerak insani sebagai bekal keterampilan hidup (life skill) sedangkan pendidikan olahraga akan mengarah kepada penguasaan suatu keterampilan cabang olahraga. Kalaupun substansi proses dari pendidikan jasmani itu berlainan namun demikian keduanya sama-sama bertendensi perilaku gerak yang bernuansakan dan bersuasanakan pendidikan.

Yang menjadi pusat perhatian pendidikan kesehatan adalah bagaimana mengintegrasikan pengetahuan, sikap, nilai dan perbuatan nyata berkenaan dengan pola hidup sehat sebagai pribadi dan warga masyarakat. 
Untuk itu model pembelajaran pendidikan kesehatan yang hanya sampai pada pembekalan pengetahuan saja sangat tidak ideal. Lebih dalam dari pengetahuan itu terdapat nilai-nilai yang kemudian menyatu dalam sikap-sikap yang baik dan buruk.

Dengan demikian pendidikan kesehatan di SD harus dilaksanakan melalui pengalaman praktis dalam pembinaan pola dan kebiasaan hidup sehat secara pribadi dan linghkungan sekitar.Substansi Pendidikan Jasmani dan Pendidikan Olahraga Pengembangan substansi pendidikan jasmani dan pendidikan olahraga pada dasarnya bertitik tolak dari kaidah yang sama yaitu penyesuaian dengan kematangan atau kesiapan belajar anak. Kesiapan belajar itu memungkinan tempo belajar berlangsung cepat. Tersangkut juga di dalamnya unsur motivasi. Karena itu dapat disimpulkan, proses belajar keterampilan motorik hanya mungkin berlangsung bila terdapat kesiapan belajar pada anak.

Pendidikan kesehatan adalah kombinasi dari pengalaman belajar yang memberi pengaruh pada cara berfikir, merasa dan berbuat yang berkaitan dengan kesehatan diri dan orang lain.

Program pendidikan kesehatan harus merupakan program yang comprehensip, melebihi sekedar memberi informasi. Sebagai bagian dari pengembangan pribadi, pendidikan kesehatan menekankan pada pembuatan keputusan yang bertanggung jawab dan mengambil langkah cocok.

Pendidikan kesehatan telah beralih dari pendekatan dengan isi yang kaku yang penuh informasi ke pendekatan dengan kepedulian atas perkembangan menyeluruh dari siswa. Fokusnya tertuju pada proses pengambilan putusan yang mencakup perolehan dan pelaksanaan pengetahuan dan pengembangan keterampilan yang perlu. Dengan demikian model pembelajaran pendidikan kesehatan tradisional yang didasarkan pada straight content dan informasi bertukar kepada model yang membimbing siswa kepada pencapaian kemampuan sikap, prilaku serta tindakan yang menjurus kepada cara hidup sehat baik secara pribadi maupuin lingkungan. Hal ini tergambar dari tujuan pendidikan kesehatan yang antara lain adalah :1) Meningkatkan sikap dan prilaku yang memberi sumbangan kepada kehidupan sehat baik pribadi maupun lingkungan; 2) 
Mengembangakan kemampuan siswa untuk mengambil keputusan tentang masalah-masalah kesehatan pribadi dan lingkungan, dan mendorong siswa untuk menerima tanggung jawab terhadap putusan-putusan tersebut; 3) Memberi informasi yang tepat tentang kesehatan dan masalah-masalah yang menyangkut kesehatan; dan 4) Mengembangkan pendekatan yng kritis terhadap faktor-faktor yang bersifat pribadi dan sosial yang mempengaruhi kualitas hidup yang disenangi baik oleh pribadi mapun masyarakat.

Kesiapan belajar itu menyangkut aspek fisik dan mental. Sehubungan dengan kaidah ini, sangat mungkin isi pendidikan olahraga disesuaikan dengan kesiapan atau kematangan anak.Seperti disinggung pada bagian terdahulu, substansi pendidikan jasmani adalah gerak insani yang dilaksanakan atas dasar kesadaran ruang, jarak dan daya. Gerak itu dikembangkan secara terpilih sehingga kita mengenal landasan-landasan ilmiah sebagai rujukan untuk memilih gerak yang bermaknaKemampuan adalah sifat yang dibawa sejak lahir atau dipelajari yang memungkinkan seseorang yang dapat menyelesaikan pekerjaannya baik secara mental maupun fisik. Dalam hal ini merupakan karakteristik stabil yang berkaitan dengan kemampuan maksimum phisik mental seseorang.

Kemampuan adalah kapasitas individu untuk melaksanakan berbagai tugas dalam pekerjaan tertentu. Seluruh kemampuan seorang individu pada hakikatnya tersusun dari perangkat kemampuan intelektual dan fisik. Kecerdasan-kecerdasan alami dan kapasitas yang diperlukan untuk menyelesaikan suatu tugas.

Keterampilan motorik merupakan sebuah proses dimana seseorang mengembangkan seperangkat respon ke dalam suatu gerak yang terkoordinasi, terorganisasi, dan terpadu (Lutan, 1988).

Keterampilan motorik berarti perkembangan pengendalian gerakan fisik melalui kegiatan syaraf dan otot yang terkoordinasi. (Hurlock, 1991). Keterampilan motorik yang sederhana biasa melibatkan beberapa koneksi motorik. Bambang Sujiono (2007: 13) berpendapat bahwa gerakan motorik kasar adalah kemampuan yang membutuhkan koordinasi sebagian besar bagian tubuh anak. Gerakan motorik kasar melibatkan aktivitas otot-otot besar seperti otot tangan, otot kaki dan seluruh tubuh anak. Sunardi dan Sunaryo, (2007: 
113-114),

menjelaskan

motorik kasar adalah kemampuan gerak tubuh yang menggunakan otot-otot besar, sebagian besar atau seluruh anggota tubuh motorik kasar diperlukan agar anak dapat duduk, menendang, berlari, naik turun tangga dan sebagainya. Hurlock dalam Endang Rini Sukamti (2007: 15), menyatakan bahwa perkembangan motorik adalah perkembangan pengendalian gerak jasmaniah melalui kegiatan pusat saraf, urat saraf, dan otot terkoordinasi. Endang Rini Sukamti (2007: 72) menjelaskan aktivitas yang menggunakan otot-otot besar di antaranya gerakan keterampilan non lokomotor, gerakan lokomotor, dan gerakan manipulatif.

Gerakan non lokomotor adalah aktivitas gerak tanpa memindahkan tubuh ke tempat lain. Contohnya antara lain, mendorong, melipat, menarik dan membungkuk. Kemudian gerakan lokomotor adalah aktivitas gerak yang memindahkan tubuh satu ke tempat lain. Contohnya antara lain, berlari, melompat, jalan dan sebagainya, sedangkan gerakan yang manipulatif adalah aktivitas gerak manipulasi benda. Contohnya, melempar, menggiring, menangkap, dan menendang.

Sukintaka (2001 : 47) bahwa kemampuan motorik merupakan kualitas hasil gerak individu dalam melakukan gerak, baik yang bukan gerak olahraga maupun gerak dalam olahraga atau kematangan penampilan keterampilan motorik.

\section{METODE}

Subjek penelitian ini adalah siswa kelas II SD Negeri Karangtengah IV tahun pelajaran 2018/ 2019 yang berjumlah 22 anak. Dalam penentuan subjek penelitian, terlebih dahulu melakukan survei pendahuluan. Objek dalam penelitian ini adalah pelaksanaan proses pembelajaran sebagai hasil dari pemanfaatan tutor sebaya dalam memberikan motivasi dalam upaya meningkatkan minat baca pada siswa.

Penelitian ini dilaksanakan di SD Negeri Karangtengah IV kelas II, lokasinya di dusun kedung I, Desa Karangtengah, Kecamatan Wonosari, Kabupaten Gunungkidul, Daerah Istimewa Yogyakarta. Sekolah tersebut mudah 
dijangkau meskipun berada di pinggiran kota kabupaten. Jalan telah beraspal sampai pintu masuk gerbang sekolah. Dampak semakin meratanya hasil pembangunan.

Penelitian dilaksanakan pada bulan Februari 2019 sampai dengan April 2019. Penelitian ini menggunakan pendekatan kualitatif deskriptif. Pada penelitian ini, kehadiran peneliti sangatlah penting, karena peneliti sebagai instrument utama sekaligus sebagai pengumpul data sepenuhnya yang mengamati atau mengadakan penelitian langsung di SD Negeri Karangtengah IV. Teknik pengumpulan data menggunakan observasi, wawancara mendalam, studi dokumentasi dan trianggulasi. Penelitian menggunakan teknik purposive sampling atau menentukan sampel dengan pertimbangan tertentu agar data yang diperoleh lebih representatif (Sugiyono, 2014:32). Teknik analisis data menggunakan Miles dan Huberman aktivitas dalam analisis data yaitu reduksi data, display (penyajian data), dan verifikasi.

Dalam pendidikan jasmani evaluasi mengandung berbagai tujuan, antara lain untuk: klasifikasi, diagnosis dan bimbingan, motivasi, laporan kemajuan dan perbaikan program.

Kita sepakat bahwa data hasil pencapaian siswa diperlukan untuk antara lain menilai efektivitas program. Evaluasi sebagai bagian integral dari proses pendidikan yang terus menerus dan berkesinambungan. Suatu program yang terencana, pada umumnya menggunakan dua cara, yakni penilaian formative dn penilaian sumative. Perbedaan mendasar dari kedua cara ini adalah bahwa penilaian formatif berlangsung sepanjang periode proses pembelajaran, sedangkan penilaian sumative dilakuakn setelah satu unit pelajaran tersebut berakhir. Penilaian formative dirancang untuk menilai keberhasilan siswa selama periode pembelajaran, untuk memformulasi atau merevisi tujuan intruksional atau teknik. Penilaian sumative ditujukan pada penilaian dari hasil keseluruhan (total) pada akhir dari suatu program belajar. Jadi penilaian sumative menekankan pada produk atau hasil belajar (learning outcome), sedangkan penilaian formative lebih menekankan pada bimbingan dalam proses pembelajaran. 
Disamping kedua cara penilaian keberhasilan siswa seperti telah diterangkan di atas, terdapat satu cara lain yang merupakan sistem yang ideal. Sistem ini tidak menerapkan nilai atau grade, suatu sistem dengan menggunakan kartu catatan, yang menunjukan objektive yang dicapai setiap siswa. Konsep gagal ditiadakan sama sekali. Kartu laporan hanya akan terdiri dari daftar objektif yang dicapai. Sistem ini mempunyai tujuan utama, pencapaian objektif oleh semua siswa, yakni objektif yang diformulasikan sebagai objektif minimal yang penting untuk dipenuhi. Promosi dari satu tingkat ketingkat berikutnya melambanghkan bahwa siswa telah mampu memperagakan keterampilan dan pengetahuan paling tidak dengan syarat minimal.

\section{HASIL DAN PEMBAHASAN}

Pengembangan substansi pendidikan jasmani dan pendidikan olahraga pada dasarnya bertitik tolak dari kaidah yang sama yaitu penyesuaian dengan kematangan atau kesiapan belajar anak. Kesiapan belajar itu memungkinan tempo belajar berlangsung cepat. Tersangkut juga di dalamnya unsur motivasi. Karena itu dapat disimpulkan, proses belajar keterampilan motorik hanya mungkin berlangsung bila terdapat kesiapan belajar pada anak.

Kesiapan belajar itu menyangkut aspek fisik dan mental. Sehubungan dengan kaidah ini, sangat mungkin isi pendidikan olahraga disesuaikan dengan kesiapan atau kematangan anak. Seperti disinggung pada bagian terdahulu, substansi pendidikan jasmani adalah gerak insani yang dilaksanakan atas dasar kesadaran ruang, jarak dan daya. Gerak itu dikembangkan secara terpilih sehingga kita mengenal landasan-landasan ilmiah sebagai rujukan untuk memilih gerak yang bermakna. Pendekatan belajar sebagai upaya efesiensi

Untuk mewujudkan tujuan pembelajaran diperlukan pendekatan-pendekatan belajar yang tepat. Sehubungan dengan hal itu telah banyak bermunculan pendekatan-pendekatan untuk meraih tujuan belajar pendidikan jasmani tersebut. Adapun jenis pendekatan beserta deskripsi sederhana dari masing-masing pendekatan yang banyak dipergunakan terutama di sekolah-sekolah Amerika ditulis oleh Adang Suherman (1998 : 5) sebagai berikut : 1) Movement Education. 
Movement Education ini pada dasarnya merupakan pendekatan yang lebih menekan pada penguasaan keterampilan gerak. Tujuan dari pendekatan ini terutama adalah untuk meningkatkan kuantitas dan kualitas gerak secara terampil, efisien, efektif pada situasi yang terencana maupun yang tidak terencana; meningkatkan pengetian, dan kesenangan terhadap gerak baik sebagai pelaku maupun sebagai penonton; meningkatkan pengetahuan dan menerapkan pengetahuan tentang gerak manusia. 2) Fitness Approach. Fitness Approach ini pada dasarnya merupakn pendekatan yang lebih menekakankan pada peningkatan penguasaan pengetahuan, keterampilan dan kualitas gerak jasmani anak didiknya. 3) Academic-Discipline Approach. Pendekatan ini pada dasarnya merupakan pendekatan yang lebih menekankan pada penguasaan pendidikan jasmani secara mendalam : bagaimana memelihara gaya hidup yang sehat, mengisi waktu senggang, menjadi pelayan atau pengguna program firness dan pendidikan jasmani di masyarakat. 4) Social-Development Model. Pendekatan ini pada dasarnya merupakan yang lebih menekankan pada perkembangan individu dan sosial anak didik. Salah satu contoh model dari pendidikan ini dikembangkan oleh Donald Hellison (1973,1978,1982) dengan istilah "teaching responsibility through physical activity" dengan menerapkan konsep "levels of affective development". 5) Sport Education Model. Pendekatan ini pada dasarnya merupakan pendekatan yang lebih menekankan pada pemeliharaan dan peningkatan nilai-nilai murni olahraga kompetitif seperti yang sering dilakukan diluar lingkungan sekolah. 6) Adventure-Education Approach. Pendekatan ini pada dasarnya merupakan pendekatan yang lebih menekankan pada aktivitasaktivitas petualangan yang penuh resiko dalam lingkungan yang lebih bersifat alami (misal, maik gunung, cross country, camping). 7) Electic Approach.

Pelaksanaan permainan lempar tangkap bola di SD Negeri Karangtengah IV kelas II dilaksanakan pada kegiatan olah raga yang dilaksanakan setiap hari Selasa.

Diperoleh hasil bahwa permainan itu mampu memperkuat motorik pada anak. Pada awalnya anak dibuat beberapa kelompok. Sebelum permainan dimulai, siapkanlah alat alat atau komponen komponen yg diperlukan untuk bermain 
lempar tangkap bola yaitu : bola, lapangan, papan sasaran, dan pemain. Siapkan jumlah pemain yg akan dimainkan yakni masing masing tim terdiri dari 22 orang. Setelah selesai, kita mulai permainan dengan jumpball yg dilakukan oleh wasit agar permainan adil.

Selanjutnya, para pemain bisa bekerja sama dengan teman setim nya saling melempar bola dengan tujuan mengenai papan sasaran lawan dengan cara melempar bola yg sesuai dengan aturan dari permainan ini. Peraturan permainan lempar tangkap bola umumnya sama dengan peraturan permainan bola biasa yaitu : terjadinya pelanggaran, cara memainkan bola, sikap terhadap sasaran, papan sasaran, lemparan bebas, lemparan kedalam, lemparan wasit, waktu dan kemenangan.

Dasar pengajaran terdapat kaitan yang erat antara berbagai unsur, seperti program strategi, kemampuan guru, keadaan murid, fasilitas dan sumber-sumber (resource) lainnya. Masing-masing unsur memegang peranan penting untuk keberhasilan pembelajaran.

Model pembelajaran yang selama ini menjadi anutan sebagian besar guru yang mengajar pendidikan jasmani dan kesehatn yakni model komando untuk pendidikan jasmani dan model ceramah untuk pendidikan kesehatan perlu diubah. Perubahan model pembelajaran ini justru dimaksud untuk menghasilkan mutu pendidikan jasmani dan kesehatan di tingkat SD.

Permainan lempar tangkap bola adalah permaianan yang dirancang untuk pendidikan jasmani yang mudah dilakukan dan dikaji melalui penelitian pengembangan baik dari cara bermain, peraturan jumlah pemain serta area lapangan untuk memberi dayatarik bagi anak-anak. Lempar tangkap bola diambil dari keterampilan gerak dasar yang ada dalam permainan ini, yaitu melempar dan menangkap. Sedangkan balo merupakan kompenen utama dari permainan ini. Permainan ini dilakukan oleh 2 tim yang masing-masing tim terdiri dari 10-15 orang pemain. Teknik dasar dari permainan ini adalah melempar dan menangkap bola. Keunikan dari permainan ini adalah cara mendapatkan poin, yaitu melempar bola ke arah papan sasaran lawan dan menyebutkan nama teman saat melempar bola merupakan keunikan lain dalam permainan ini karena belum ada dalam 
permainan yang lain. Ini bertujuan untuk meningkatkan rasa keakraban antar anak, sehingga kerjasama antar anak-anak lebih baik dan mereka lebih memiliki rasa peduli terhadap anggota kelompok. Hal ini juga bertujuan untuk mendorong siswa lebih berkomunikasi dengan teman. Selain itu cara mendapatkan poin juga berbeda dengan permainan lain, yaitu dengan melempar bola tepat mengenai papan sasaran lawan masing-masing. Pemenang dalam permainan ini adalah tim yang mendapatkan poin terbanyak. Kompenen-kompenen Permainan Lempar Tangkap Bola, adalah bola.

Bola merupakan salah satu kompenen yang terdapat dalam permaianan ini. Bola yang digunakan bisa menggunakan bola voli karena lebih ringan dibandingkan dengan bola basket atau bola sepak bola. Komponen yang kedua adalah lapangan.

Lapangan yang digunakan dalam permainan lempar tangkap bola adalah 6 x $12 \mathrm{~m}$. Lapangan menggunakan ukuran lapangan bola voli mini yang sudah sesuai dengan karakteristik anak-anak, sehingga diharapkan ketika melakukan permainan lempar tangkap bola anak-anak lebih aktif bergerak dalam permainan sehingga kesegaran jasmani anak-anak bisa lebih baik. Dengan penggunaan lapangan yang relatif kecil diharapkan bisa menyediakan 2 lapangan dengan ukuran 6x12 m sehingga pembelajaran yang efektif terhadap anak didik bisa terwujud. Komponen berikutnya adalah papan sasaran.

Papan sasaran yang digunakan bisa terbuat dari kayu atau tirplek, berbentuk kotak dan memiliki ukuran 40 x $60 \mathrm{~cm}$. Ukuran papan lebih besar dari bola, diharapkan dapat mempermudah siswa dalam mendapatkan poin. Selanjutnya yang ada adalah pemain.

Pemain merupakan komponen pokok dari permainan ini, karena tanpa adanya pemain permainan ini tidak bisa dimainkan. Dalam satu tim pada permainan ini berjumlah 10-15, karena di SD Negeri Karangtengah IV kelas II ada 22 orang pemain, maka permainan boleh melibatkan 22 pemain, jadi dalam satu lapangan terdapat 22 pemain yang akan melakukan permainan ini baik itu perempuan maupun laki-laki. 


\section{Cara Bermain Lempar Tangkap Bola}

Sebelum permainan ini dimulai, ada baiknya kita mempersiapkan alat-alat atau komponen-komponen yang diperlukan dalam permainan lempar tangkap bola. Seperti yang telah disebutkan sebelumnya, yaitu bola, lapangan, papan sasaran, dan pemain. Jika lapangan yang digunakan terlalu besar, maka kita bisa mebatasinya dengan menandai atau memberi garis sisi luar lapangan tersebut. Papan sasaran kita taruh di setiap wilayah pemain, di bagian paling belakang dengan satu orang penjaga. Siapkan jumlah pemain yang akan dimainkan yakni masing-masing tim terdiri dari 10-15 orang pemain dan sebuah bola tentunya.

Setelah selesai melakukan persiapan, kita mulai permainan ini dengan jumpball yang dilakukan oleh seorang wasit, hal ini dilakukan agar supaya permainan adil. Selanjutnya, para pemain bisa berkerjasama dengan teman setimnya saling melempar dan menangkap bola dengan tujuan mengenai papan sasaran lawan dengan cara melempar bola tersbut yang sesuai dengan aturan dari permainan ini. Peraturan dalam permainan lempar tangkap bola hampir sama dengan peraturan permainan bola tangan pada umumnya. Adapun aturan-aturan yang harus ditaati oleh pemaian, yaitu:

Pelanggaran terjadi jika pemain sengaja melakukan sesuatu yang dilarang seperti yang akan dijelaskan: Bersikap tidak sopan terhadap wasit. Cara memainkan bola yang diperbolehkan. Bola boleh mengenai seluruh anggota badan. Melempar atau menangkap bola, boleh dengan satu atau dua tangan. Waktu memegang bola paling lama hanya 10 detik. Memainkan bola dari satu teman ke teman yang lain. Melempar bola ke arah teman harus dengan menyebutkan inisial nama teman.Yang dilarang/pelanggaran:Tidak boleh menyentuh bola dengan tungkai bawah dan kaki. Tidak boleh menyentuh bola lebih dari satu kali jika bola belum menyentuh pemain lain. Jika menyentuh bola dengan tungkai atau kaki maka terjadi pelanggaran. Jika bola ke luar garis lapangan maka terjadi lemparan ke dalam.

Jika lupa menyebutkan inisial nama teman ketika melempar bola maka dihukum lemparan bebas. Sengaja melempar bola ke luar lapangan, maka dihukum lemparan bebas. Tidak boleh memegang bola selama lebih dari 10 detik, 
maka dihukum lemparan bebas. Sikap terhadap lawan yang boleh dilakukan: menepis bola dari tangan lawan ketika bola dilempar. menghadang jalan lawan dengan tubuh ketika akan melempar bola.

Yang dilarang/pelanggaran:Tidak boleh merebut secara paksa atau memukul bola yang dipegang oleh lawan. Tidak boleh menjatuhkan lawan dengan sengaja. Tidak boleh dengan sengaja melempar bola ke badan lawan. Bersikap keras dengan lawan, seperti menarik baju, mendorong, memukul, berbicara kotor dll. Papan sasaran Boleh melempar bola ke arah papan sasaran dengan jarak yang tidak ditentukan asalkan tidak melewati garis gawang. Lemparan bebas Dilakukan ketika terjadi pelanggaran. Pelaksanaannya tepat dimana terjadi pelanggaran. Lemparan bebas bisa langsung menghasilkan poin. Lemparan dilakukan menunggu peluit dari wasit. Lemparan ke dalam Dilakukan ketika bola keluar dari garis lapangan.

Cara melakukannya dengan salah satu kaki menyentuh tanah, tidak boleh terangkat dan bola dilempar dengan menggunakan kedua tangan dari belakang kepala. Lemparan wasit mengawali jalannya permainalan, bola dilempar ke atas (jump ball). Jump ball juga dilakukan ketika kedua tim melakukan pelanggaran bersamaan. Waktu yang digunakan dalam permainan ini adalah 2 x 15 menit.

Tim yang dinyatakan memenang dalam permainan adalah tim yang mendapatkan poin terbanyak dalam waktu yang sudah ditentukan. Untuk hal itu, bukan sekedar mengemukakan dan menganjurkan penggunaan model pembelajaran yang tepat saja yang diperlukan, akan tetapi yang tidak kalah pentingnya adalah sikap para guru sendiri. Guru penjaskes harus senantiasa ikut berfikir dan mencari jalan dan memecahkan masalah hingga mutu pendidikan jasmani dan kesehatan di SD terus dapat ditingkatkan. Sehingga diharapkan pendidikan jasmani dan kesehatan dapat mencapai tujuan khusus penjaskes dan tujuan pendidikan umumnya.

Lima Manfaat Bermain Lempar Tangkap Bola, Ada yang pernah mengajak anaknya untuk bermain Lempar Tangkap Bola? Permainan ini mungkin bukanlah permainan yang asing bagi kita sebagai orang tua, tapi belum tentu bagi anak. Di tengah berkembangnya jenis permainan yang mengandalkan gadget ataupun jenis 
audiovisual yang lain, bermain lempar tangkap bola mungkin bisa menjadi permainan yang "asing" bagi anak-anak.

Dari pembelajaran olah raga di SD Negeri Karangtengah IV, permainan lempar tangkap bola, sangat digemari oleh siswa. Antara siswa putra dan putri mampu berkegiatan bersama. Hal ini yang dapat dirasakan oleh anak-anak tersebut.

\section{SIMPULAN}

Berdasarkan hasil penelitian diperoleh hasil bahwa Permainan Lempar Tangkap Bola berpengaruh terhadap kinerja motoric anak terutama anak usia 8 sampai dengan 9 tahun. Dalam hal lempar tangkap bola ini membuat anak mampu berintegrasi dengan teman sejawatnya, dan mampu mengembangkan motoriknya. Kesimpulan yang di dapat adalah bahwa permainan lempar tangkap bola yang dilaksanakan di SD Negeri Karangtengah IV pada kelas II, mampu meningkatkan motorik anak, khususnya pada perkembangan 8-9 tahun.

\section{DAFTAR PUSTKA}

Stepen.P. Robbins.(2003). Perilaku Organisasi, Yogyakarta: Pramita

Sujiono, Bambang. 2007. Metode Pengembangan Fisik (Edisi Revisi). Jakarta: Universitas Terbuka.

Sukamti, Endang Rini. 2007. Perkembangan Motorik. Yogyakarta: UNY.

Sukintaka. (2001). Teori Pendidikan Jasmani. Solo: Esa Grafika.

Sunardi dan Sunaryo. 2007. Intervensi Dini Anak Berkebutuhan Khusus. Jakarta: Depdiknas. 